\title{
Optimasi Site Layout Menggunakan Multi-Objectives Function pada Proyek Pembangunan Transmart Rungkut Surabaya
}

\author{
Handi Destianno Adhika dan Cahyono Bintang Nurcahyo \\ Jurusan Teknik Sipil, Fakultas Teknik Sipil dan Perencanaan, Institut Teknologi Sepuluh Nopember (ITS) \\ Jl. Arief Rahman Hakim, Surabaya 60111 Indonesia \\ e-mail:bintang@ce.its.ac.id
}

\begin{abstract}
Abstrak-Proyek konstruksi bangunan selalu diikuti dengan pembangunan fasilitas-fasilitas pendukung sementara di sekitarnya yang berguna sebagai penunjang jalannya proyek konstruksi. Seringkali perencanaan penempatan fasilitas pendukung tersebut belum direcanakan secara optimal, sehingga perlu dilakukan optimasi site layout dengan mengatur letak fasilitas pendukung sementara yang diharapkan dapat meningkatkan produktivitas dan keselamatan kerja secara efisien. Pada penelitian ini site layout akan dioptimasi menggunakan multi-objectives function dengan fungsi objektif yang ingin dicapai adalah Traveling Distance (TD) dan Safety Index (SI) yang minimum. Perhitungan optimasi pada Penelitian ini akan dilakukan dengan membuat beberapa alternatif perpindahan fasilitas dengan cara memindahkan fasilitas satu ke fasilitas lainnya dengan tetap memperhatikan luasan masing-masing fasilitas. Proyek yang digunakan sebagai objek penelitian adalah Proyek Pembangunan Transmart Rungkut Surabaya yang memiliki tinggi 4 lantai dan terletak di Jl. Raya Kali Rungkut No.25. Dari 15 alternatif perpindahan, didapatkan dari hasil plot pada diagram bahwa alternatif yang paling optimum adalah Alternatif 9 dan Alternatif 12. Dari perhitungan Traveling Distance diperoleh bahwa hasil TD paling minimum yaitu ada Alternatif 9 sebesar $\mathbf{5 8 . 4 0 9 , 5}$ meter atau mengalami penurunan nilai TD sebesar 10,10\% bila dibandingkan dengan kondisi asli. Sedangkan dari hasil perhitungan Safety Index diperoleh bahwa hasil SI paling minimum yaitu pada Alternatif 12 sebesar 2314,69 atau mengalami penurunan nilai SI sebesar $9,01 \%$ bila dibandingkan dengan kondisi asli. Sedangkan untuk menentukan Alternatif yang paling optimum digunakan pembobotan, dengan nilai 30\% Traveling Distance dan 70\% Safety Index. Dari hasil perhitungan pembobotan didapat nilai Alternatif 9 sebesar 8,26\% dan Alternatif 12 sebesar 7,40\%. Nilai pembobotan paling besar artinya paling optimum, sehingga Alternatif 9 dipilih sebagai alternatif yang paling optimum.
\end{abstract}

Kata Kunci-Multi-Objectives Function, Optimasi, Safety Index, Site Layout, Traveling Distance.

\section{PENDAHULUAN}

$\mathrm{D}$ EWASA ini, seiring berjalannya waktu dan perkembangan teknologi yang sangat pesat membuat persaingan pada dunia konstruksi menuntut perusahaan-perusahaan kontraktor untuk melakukan efisiensi di berbagai aspek produksi. Masih banyak perusahaan kontraktor yang belum memperhatikan beberapa faktor yang sebenarnya memiliki potensi untuk dioptimalkan sehingga pekerjaan dapat dilakukan dengan lebih efisien. Salah satu yang dapat dilakukan perusahaan kontraktor untuk mengoptimalkan kinerja di lapangan yaitu dengan cara mengoptimalkan tata letak fasilitas pada proyek. Sehingga pelaksanaan pekerjaan proyek dapat lebih efisien, hemat waktu, produktivitas meningkat, dan hasil kerja yang optimal.

Optimasi site layout (tata letak) sendiri merupakan sutau tahapan dalam perencanaan fasilitas pendukung proyek yang bertujuan untuk mendapatkan tata letak yang efisien dan efektif sehingga hasil kerja menjadi optimal. Perencanaan site layout meliputi identifikasi fasilitas-fasilitas pendukung pekerjaan pada proyek, menentukan ukuran dan bentuk fasilitas-fasilitas tersebut pada lokasi yang tersedia (Tommelein, dkk, 1991) [1]. Tata letak fasilitas pendukung tersebut memiliki dampak yang sangat penting bagi proses pengerjaan proyek karena mencakup waktu pekerjaan dan biaya proyek. Setiap proyek tentunya memiliki luas lahan yang berbeda-beda serta memerlukan fasilitas yang berbeda pula dalam pelaksanaan proyek (Yeh, 1995) [2].

Perencanaan site layout sendiri dibagi menjadi dua, yaitu equal site layout dan unequal site layout. Equal site layout adalah kondisi dimana jumlah lokasi yang tersedia pada area proyek sama dengan jumlah lokasi yang dibutuhkan untuk penempatan fasilitas proyek yang ada, sedangkan unequal site layout merupakan kondisi dimana jumlah lokasi yang tersedia lebih banyak daripada jumlah lokasi yang dibutuhkan untuk penempatan fasilitas yang ada di proyek.

Pada penelitian ini, perencanaan site layout akan mempertimbangkan jarak tempuh yang dilalui pekerja antar fasilitas pendukung proyek (traveling distance) dan juga keamanan dan keselamatan pekerja di lapangan (safety index). Jarak tempuh ini merupakan jarak kumulatif pekerja yang bergerak dari satu fasilitas ke fasilitas lainnya setiap harinya. Sedangkan keamanan dan keselamatan perlu dipertimbangkan juga dalam merencanakan site layout untuk menghidari hal-hal yang tidak diinginkan dalam pengerjaan proyek. Karena penempatan fasilitas pendukung yang salah dapat berakibat fatal apabila keselamatan dan keamanan pekerja tidak dipertimbangkan.

Proyek pembangunan Transmart Rungkut yang berlokasi di J1. Kali Rungkut, Surabaya merupakan gedung dengan ketinggian 4 lantai. Proyek yang dikerjakan dengan kontraktor PT. PP (Persero) Tbk. ini memiliki lahan proyek yang tergolong sempit namun dengan fasilitas-fasilitas penunjang yang cukup banyak. Penempatan fasilitas-fasilitas tersebut masih belum maksimal melihat dari kondisi di lapangan, dengan frekuensi pergerakan pekerja yang tinggi di beberapa fasilitas, yang berpengaruh pada produktivitas perkerja dan juga efisiensinya. Selain itu dilihat dari keselamatan para pekerjanya, proyek ini memiki 1 buah Tower Crane, genset listrik, dan juga gudang 
penyimpanan BBM yang dapat menimbulkan bahaya bagi para pekerja di proyek tersebut. Ketidakteraturan ini dapat diantisipasi dengan mengukur seberapa besar tingkat bahaya (safety index) berdasarkan layout awal yang ada. Oleh karena itu, perlu adanya perbaikan dalam pengaturan site layout berdasarkan traveling distance dan safety index pada proyek ini.

Pengoptimalan site layout ini diharapkan dapat memberikan beberapa alternatif tata letak yang optimal dengan cara mengatur fasilitas-fasilitas pendukung proyek. Hal ini tentunya menjadi masukan yang positif bagi kontraktor terkait dalam pengerjaan proyek Transmart Rungkut Surabaya ini.

\section{METODOLOGI}

Pada penelitian ini akan membahas tentang optimasi site layout menggunakan proyek pembangunan Transmart Rungkut Surabaya. Berikut langkah-langkah yang diambil untuk mendukung proses penelitian yang akan dibuat agar penelitian dapat berjalan lebih terarah dan sistematis.

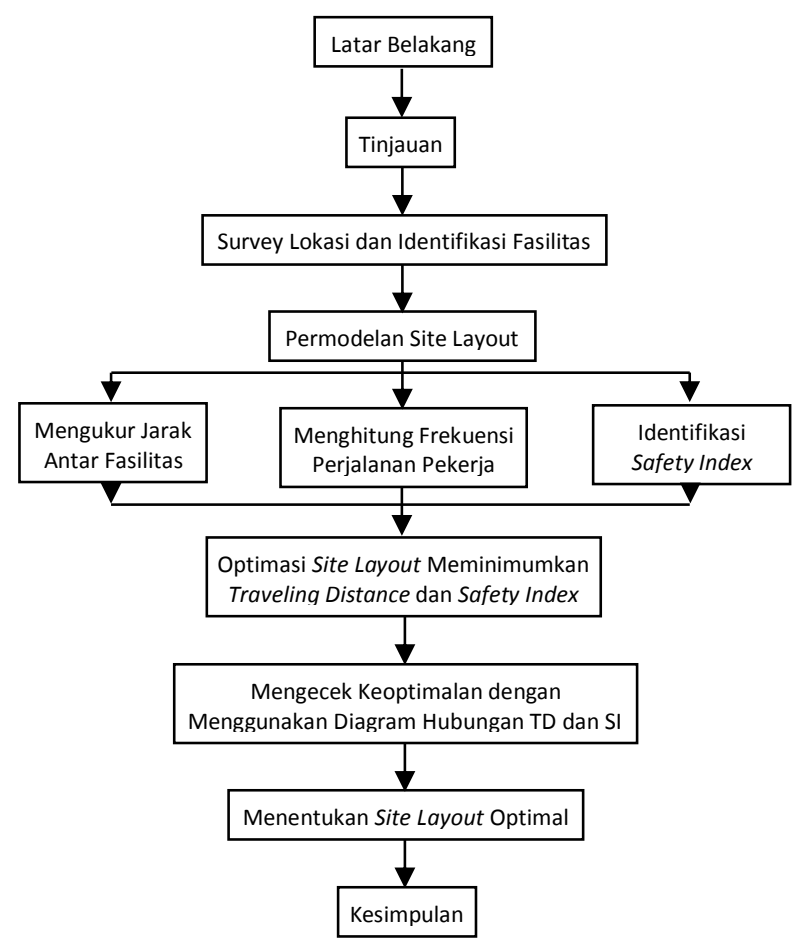

Gambar 1. Bagan Alir Penelitian

Penjelasan lebih lanjut mengenai bagan alir penelitian serta metodologi dapat dilihat di Adhika, H. A. (2016).

\section{PEMBAHASAN}

\section{A. Survei dan Pengumpulan Data}

Survei lokasi proyek dilakukan pada proyek pembangunan Transmart Rungkut Surabaya. Proyek ini terletak di Jl. Raya Kalirungkut dan posisi bangunannya langsung menghadap ke arah jalan tersebut, dengan kontraktor yang bertanggungjawab pada proyek ini adalah PT. PP (Persero) Tbk. Proyek Tansmart ini merupakan bangunan 4 lantai yang terdiri dari pusat perbelanjaan, area bermain anak, dan juga bioskop pada bagian belakang gedung. Survey ini sendiri dilakukan untuk memperoleh data tata letak fasilitas, ukuran tiap-tiap fasilitas, jarak antar fasilitas, frekuensi perjalanan pekerja antar fasilitas dan identifikasi nilai safety.

Dari hasil survey yang dilakukan melalui proses pengamtan langsung di lapangan dan juga wawancara dengan beberapa staff dari PT. PP (Persero) Tbk., maka didapatkan data sebagai berikut.

a. Identifikasi fasilitas proyek, mengetahui jumlah fasilitas, jenis, dan luasan

Tabel 1.

Fasilitas-Fasilitas Proyek

\begin{tabular}{clc}
\multicolumn{3}{c}{ Fasilitas-Fasilitas Proyek } \\
\hline \hline & & \\
No & \multicolumn{1}{c}{ Fasilitas } & Luas (m2) \\
& & \\
\hline 1 & Kantor Operasional & 33 \\
2 & Parkir & 54 \\
3 & Toilet dan Musholla & 26 \\
4 & Gudang Logistik & 35 \\
5 & Gudang Peralatan & 40 \\
6 & Subkon Office & 66 \\
7 & Genset & 5.5 \\
8 & Rumah B3 \& BBM & 4 \\
9 & Fabrikasi Besi & 142 \\
10 & Fabrikasi Baja & 156 \\
11 & Kantor K3 & 33 \\
12 & Los Kerja Kayu & 74 \\
\hline \hline
\end{tabular}

b. Jarak antar fasilitas, diperoleh langsung di lapangan sesuai dengan rute pergerakan pekerja ketika berpindah dari satu fasilitas ke fasilitas lainnya.

Tabel 2.

Jarak Antar Fasilitas Pendukung

\begin{tabular}{|l|c|c|c|c|c|c|c|c|c|c|c|c|}
\hline JENIS FASLLIT AS & $\begin{array}{c}\text { Site } \\
\text { Office }\end{array}$ & Parkir & $\begin{array}{c}\text { Toilet \& } \\
\text { Musholla }\end{array}$ & $\begin{array}{c}\text { Gudang } \\
\text { Logistik }\end{array}$ & $\begin{array}{c}\text { Gudang } \\
\text { Peralatan }\end{array}$ & $\begin{array}{c}\text { Subkon } \\
\text { Office }\end{array}$ & Genset & $\begin{array}{c}\text { Rumah B3 } \\
\text { \& BBM }\end{array}$ & $\begin{array}{c}\text { Fabrikasi } \\
\text { Besi }\end{array}$ & $\begin{array}{c}\text { Fabrikasi } \\
\text { Baja }\end{array}$ & $\begin{array}{c}\text { Kantor } \\
\text { K3 }\end{array}$ & $\begin{array}{c}\text { Los Kerja } \\
\text { Kayu }\end{array}$ \\
\hline Site Office & 0 & 21.5 & 23.8 & 34.1 & 41.6 & 50.2 & 23.9 & 44.2 & 34.4 & 28.2 & 2.4 & 69.4 \\
\hline Parkii & 21.5 & 0 & 6.3 & 49.4 & 57.6 & 65.1 & 39.4 & 56.2 & 45.4 & 54.9 & 18.3 & 83.4 \\
\hline Toilet \& Musholla & 23.8 & 6.3 & 0 & 54.5 & 60.1 & 68.2 & 41.6 & 61.3 & 50.8 & 49.2 & 19.2 & 85.6 \\
\hline Gudang Logistik & 34.2 & 49.4 & 54.5 & 0 & 8.3 & 15.9 & 21.2 & 40.7 & 35.2 & 27.8 & 40.3 & 59.1 \\
\hline Gudang Peralatan & 41.6 & 57.6 & 60.1 & 8.3 & 0 & 9.9 & 28.6 & 54.3 & 35.4 & 41.7 & 46.8 & 70.3 \\
\hline Subkon Office & 50.2 & 65.1 & 68.2 & 15.9 & 9.9 & 0 & 43.3 & 65.2 & 47.3 & 54.3 & 53.7 & 79.3 \\
\hline Genset & 23.9 & 39.4 & 41.6 & 21.2 & 28.6 & 43.3 & 0 & 24.5 & 9.8 & 8.7 & 38.2 & 35.7 \\
\hline Rumah B3 \& BBM & 44.2 & 56.2 & 61.3 & 40.7 & 54.3 & 65.2 & 24.5 & 0 & 43.3 & 8.5 & 46.2 & 61.5 \\
\hline Fabrikasi Besi & 34.4 & 45.4 & 50.8 & 35.2 & 35.4 & 47.3 & 9.8 & 43.3 & 0 & 19.1 & 37.9 & 19.3 \\
\hline Fabrikasi Baja & 28.2 & 54.9 & 49.2 & 27.8 & 41.7 & 54.3 & 8.7 & 8.5 & 19.1 & 0 & 31.2 & 41.8 \\
\hline Kantor K3 & 2.4 & 18.3 & 19.2 & 40.3 & 46.8 & 53.7 & 38.2 & 46.2 & 37.9 & 31.2 & 0 & 72.1 \\
\hline Los Kerja Kayu & 69.4 & 83.4 & 85.6 & 59.1 & 70.3 & 79.3 & 35.7 & 61.5 & 19.3 & 41.8 & 72.1 & 0 \\
\hline & & & & & & & & & & & & \\
\hline
\end{tabular}

c. Frekuensi pergerakan pekerja antar fasilitas, diperoleh dari proses pengamatan langsung di lapangan. Frekuensi perjalanan pekerja dari fasilitas A ke B diasumsikan sama dengan frekuensi dari B ke A.

Tabel 3.

Frekuensi Perjalanan Pekerja (1hari)

\begin{tabular}{|l|c|c|c|c|c|c|c|c|c|c|c|c|}
\hline JENIS FASILIT AS & $\begin{array}{c}\text { Site } \\
\text { Office }\end{array}$ & $\begin{array}{c}\text { Parkir } \\
\text { Toilet \& }\end{array}$ & $\begin{array}{c}\text { Gudang } \\
\text { Musholla }\end{array}$ & $\begin{array}{c}\text { Gudang } \\
\text { Peralatan }\end{array}$ & $\begin{array}{c}\text { Subkon } \\
\text { Office }\end{array}$ & $\begin{array}{c}\text { Genset } \\
\text { Rumah B3 } \\
\& \text { BBM }\end{array}$ & $\begin{array}{c}\text { Fabrikasi } \\
\text { Besi }\end{array}$ & $\begin{array}{c}\text { Fabrikasi } \\
\text { Baja }\end{array}$ & $\begin{array}{c}\text { Kantor } \\
\text { K3 }\end{array}$ & $\begin{array}{c}\text { Los Kerja } \\
\text { Kayu }\end{array}$ \\
\hline Site Office & 0 & 65 & 75 & 14 & 22 & 5 & 1 & 1 & 15 & 9 & 15 & 11 \\
\hline Parkir & 65 & 0 & 36 & 17 & 25 & 8 & 2 & 0 & 7 & 15 & 14 & 10 \\
\hline Toilet \& Musholla & 75 & 36 & 0 & 23 & 35 & 10 & 1 & 3 & 42 & 51 & 30 & 26 \\
\hline Gudang Logistik & 14 & 17 & 23 & 0 & 10 & 4 & 1 & 1 & 8 & 5 & 15 & 17 \\
\hline Gudang Peralatan & 22 & 25 & 35 & 10 & 0 & 3 & 3 & 2 & 15 & 11 & 12 & 8 \\
\hline Subkon Office & 5 & 8 & 10 & 4 & 3 & 0 & 0 & 0 & 2 & 4 & 10 & 3 \\
\hline Genset & 1 & 2 & 1 & 1 & 3 & 0 & 0 & 1 & 0 & 0 & 2 & 0 \\
\hline Rumah B3 \& BBM & 1 & 0 & 3 & 1 & 2 & 0 & 1 & 0 & 2 & 1 & 4 & 1 \\
\hline Fabrikas Besi & 15 & 7 & 42 & 8 & 15 & 2 & 0 & 2 & 0 & 20 & 15 & 30 \\
\hline Fabrikasi Baja & 9 & 15 & 51 & 5 & 11 & 4 & 0 & 1 & 20 & 0 & 10 & 16 \\
\hline Kantor K3 & 15 & 14 & 30 & 15 & 12 & 10 & 2 & 4 & 15 & 10 & 0 & 5 \\
\hline Los Kerja Kayu & 11 & 10 & 26 & 17 & 8 & 3 & 0 & 1 & 30 & 16 & 5 & 0 \\
\hline & & & & & & & & & & & & \\
\hline
\end{tabular}


d. Safety Index, dari hasil wawancara dengan K3 officer di lapangan mengenai tingkat bahaya kecelakaan kerja pada seluruh zona proyek. Maka didapat 4 zona kecelakaan kerja yang memungkinkan terjadi dan juga kriteria untuk masingmasing zona bahaya. Lebih jelasnya dapat dilihat pada tabel 4 berikut :

Tabel 4.

Kriteria Nilai Safety

\begin{tabular}{cc}
\hline \hline $\begin{array}{c}\text { Nilai } \\
\text { Safety }\end{array}$ & Keterangan \\
\hline 1 & $\begin{array}{c}\text { Di luar radius zona bahaya perputaran lengan Tower Crane, zona } \\
\text { bahaya Genset dan zona bahaya Rumah B3 \& BBM }\end{array}$ \\
2 & $\begin{array}{c}\text { Zona bahaya tersengat tegangan listrik Genset/ledakan Rumah B3 } \\
\text { \& BBM }\end{array}$ \\
3 & $\begin{array}{c}\text { Zona bahaya perputaran lengan Tower Crane dengan radius 60 m } \\
4\end{array}$ \\
& $\begin{array}{c}\text { Zona bahaya gabungan perputaran lengan Tower Crane dan } \\
\text { tegangan listrik Genset/ledakan Rumah B3 dan BBM }\end{array}$ \\
\hline \hline
\end{tabular}

Kriteria nilai safety pada tabel 4 tersebut digunakan untuk menghitung nilai safety dengan menggunakan proporsi jarak antar fasilitas. Hasil dari perhitungan tersebut bisa dilihat pada tabel 5 berikut :

Tabel 5.

Nilai Safety Antar Fasilitas

\begin{tabular}{|c|c|c|c|c|c|c|c|c|c|c|c|c|}
\hline SFAS & \begin{tabular}{|l|} 
Site \\
Office
\end{tabular} & $\begin{array}{l}\text { Parkir } \\
\end{array}$ & $\begin{array}{l}\text { Toilet \& } \\
\text { Musholla }\end{array}$ & $\begin{array}{l}\begin{array}{l}\text { Gudang } \\
\text { Logistik }\end{array} \\
\end{array}$ & 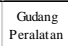 & $\begin{array}{c}\begin{array}{c}\text { Subkon } \\
\text { Office }\end{array} \\
\text { of }\end{array}$ & Genset & $\begin{array}{c}\text { Rumah B33 } \\
\& \text { BBM }\end{array}$ & $\begin{array}{c}\text { Fabrikasi } \\
\text { Besi }\end{array}$ & $\begin{array}{c}\text { Fabrikasi } \\
\text { Baja }\end{array}$ & $\begin{array}{c}\text { Kantor } \\
\text { K3 }\end{array}$ & $\begin{array}{c}\text { Los Kerja } \\
\text { Kayu }\end{array}$ \\
\hline office & 0 & 1 & 1 & 1 & 1 & 1 & 1.603 & 1.733 & 2.291 & 2.181 & 1 & 2.442 \\
\hline Parkir & 1 & 0 & 1 & 1 & 1 & 1 & 1.546 & 1.719 & .934 & 625 & 0 & 200 \\
\hline sholla & 1 & 1 & 0 & & & & 1.363 & 1.440 & 1.868 & 1.709 & 1 & 169 \\
\hline & 1 & 1 & & & & & & & & & & 94 \\
\hline & 1 & 1 & & & 0 & & 1.654 & 1.928 & 833 & & 1 & \\
\hline on of & 1 & 1 & 1 & 1 & 1 & 0 & 1.293 & 17 & 113 & 1.753 & 1 & 2.262 \\
\hline Genset & 1.603 & 1.546 & 1.3 & 1.774 & 1.654 & 1.293 & & & & & 319 & 3.221 \\
\hline & 3 & 1.71 & 1.440 & 2.157 & 1.92 & 1.317 & 3.069 & & 2.702 & 2.753 & 978 & 3.195 \\
\hline & 2.291 & 4 & 1.868 & 1.9 & 1.83 & 1.913 & 3.102 & 2.702 & 0 & 3.052 & 1.763 & \\
\hline Fabriksi & 2.181 & 1.625 & 1.709 & 2.662 & 2.017 & 1.753 & 4 & 2.753 & 3.052 & 0 & 2.141 & 3.337 \\
\hline & & & & & & & 1.319 & 1.978 & 1.763 & 141 & 0 & 2.388 \\
\hline s Kerja Kayu & 2.442 & 2.200 & 2.169 & 2.694 & 2.424 & 2.262 & 3.221 & 3.195 & 3 & 3.337 & 2.388 & 0 \\
\hline
\end{tabular}

e. Gambar model site layout, sesuai dengan data yang sudah di peroleh. Gambar site layout asli pada gambar 2 berikut :

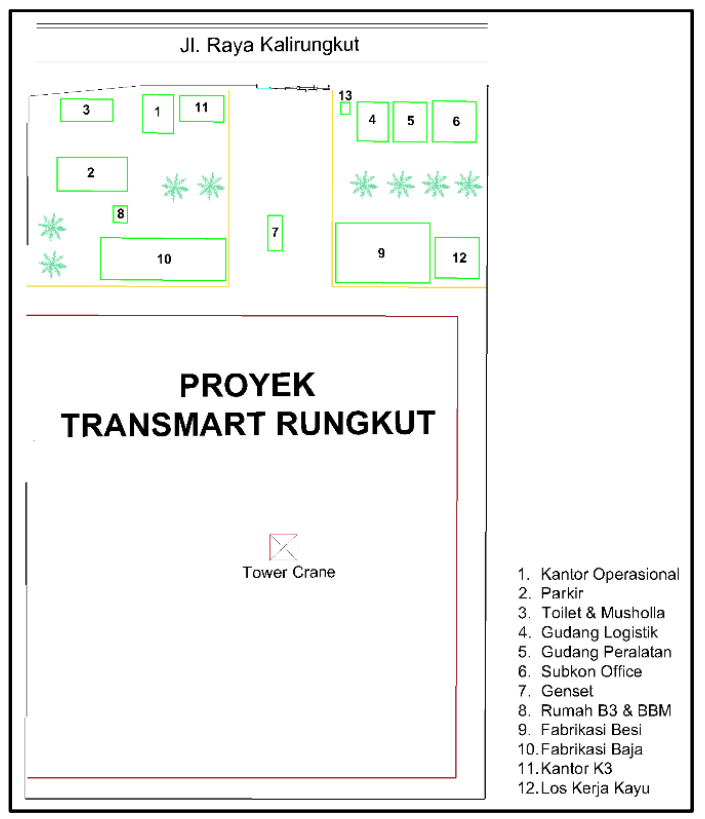

Gambar 2. Site Layout Eksisting

\section{B. Perhitungan Optimasi}

Setelah didapat data dari hasil survey dan juga dari PT. PP (Persero) Tbk. selaku kontraktor, maka dapat dilakukan perhitungan Traveling Distance dan Safety Index. Proses optimasi dilakukan menggunakan 15 alternatif yang sudah direncanakan sebelumnya. Berikut merupakan perhitungan masing-masing alternatif :

Tabel 6.

Alternatif-Alternatif Perpindahan Fasilitas

\begin{tabular}{|c|c|c|c|c|c|c|c|c|c|c|c|c|}
\hline \multirow[b]{2}{*}{ Alt. } & \multicolumn{12}{|c|}{ LOKASI FASILITAS } \\
\hline & 1 & 2 & 3 & 4 & 5 & 6 & 7 & 8 & 9 & 10 & 11 & 12 \\
\hline 0 & $\begin{array}{c}\text { Site } \\
\text { Office }\end{array}$ & P & $\begin{array}{l}\text { Toilet \& } \\
\text { Musholla }\end{array}$ & $\begin{array}{l}\text { Gudang } \\
\text { Logistik }\end{array}$ & $\begin{array}{c}\text { Gudang } \\
\text { Peralatan }\end{array}$ & $\begin{array}{l}\text { Subkon } \\
\text { Office }\end{array}$ & enset & $\begin{array}{c}\text { Rumah B3 } \\
\text { \& BBM }\end{array}$ & $\begin{array}{c}\text { Fabrikasi } \\
\text { Besi }\end{array}$ & $\begin{array}{c}\text { Fabrikasi } \\
\text { Baja }\end{array}$ & $\begin{array}{c}\text { Kantor } \\
\mathrm{K} 3\end{array}$ & $\begin{array}{c}\text { Los Kerja } \\
\text { Kayu }\end{array}$ \\
\hline 1 & $\begin{array}{c}\text { Site } \\
\text { Office }\end{array}$ & kir & $\begin{array}{l}\text { Toilet \& } \\
\text { Musholla }\end{array}$ & $\begin{array}{l}\text { Gudang } \\
\text { Logistik }\end{array}$ & $\begin{array}{l}\text { Gudang } \\
\text { Peralatan }\end{array}$ & $\begin{array}{c}\text { Subkon } \\
\text { Office }\end{array}$ & Genset & $\begin{array}{c}\text { Rumah B3 } \\
\text { \& BBM }\end{array}$ & $\begin{array}{c}\text { Fabrikasi } \\
\text { Baja }\end{array}$ & $\begin{array}{c}\text { Fabrikasi } \\
\text { Besi }\end{array}$ & $\begin{array}{c}\text { Kantor } \\
\mathrm{K} 3\end{array}$ & $\begin{array}{c}\text { Los Kerja } \\
\text { Kayu }\end{array}$ \\
\hline 2 & $\begin{array}{c}\text { Site } \\
\text { Office }\end{array}$ & Parkir & $\begin{array}{l}\text { Toilet \& } \\
\text { Musholla }\end{array}$ & $\begin{array}{l}\text { Gudang } \\
\text { Peralatan }\end{array}$ & $\begin{array}{l}\text { Gudang } \\
\text { Logistik }\end{array}$ & $\begin{array}{l}\text { Subkon } \\
\text { Office }\end{array}$ & Genset & $\begin{array}{c}\text { Rumah B3 } \\
\& \text { BBM }\end{array}$ & $\begin{array}{c}\text { Fabrikasi } \\
\text { Besi }\end{array}$ & $\begin{array}{c}\text { Fabrikasi } \\
\text { Baja }\end{array}$ & $\begin{array}{c}\text { Kantor } \\
\text { K3 }\end{array}$ & $\begin{array}{l}\text { Los Kerja } \\
\text { Kayu }\end{array}$ \\
\hline 3 & $\begin{array}{c}\text { Site } \\
\text { Office }\end{array}$ & Parkir & $\begin{array}{l}\text { Toilet \& } \\
\text { Musholla }\end{array}$ & $\begin{array}{l}\text { Gudang } \\
\text { Logistik }\end{array}$ & $\begin{array}{l}\text { Gudang } \\
\text { Peralatan }\end{array}$ & $\begin{array}{c}\text { Los Kerja } \\
\text { Kayu }\end{array}$ & Genset & $\begin{array}{c}\text { Rumah B3 } \\
\text { \& BBM }\end{array}$ & $\begin{array}{c}\text { Fabrikasi } \\
\text { Besi }\end{array}$ & $\begin{array}{c}\text { Fabrikasi } \\
\text { Baja }\end{array}$ & $\begin{array}{c}\text { Kantor } \\
\text { K3 }\end{array}$ & \\
\hline 4 & $\begin{array}{c}\text { Site } \\
\text { Office }\end{array}$ & $\mathrm{P}$ & $\begin{array}{l}\text { Toilet \& } \\
\text { Musholla }\end{array}$ & $\begin{array}{c}\text { Kantor } \\
\text { K3 }\end{array}$ & $\begin{array}{l}\text { Gudang } \\
\text { Peralatan }\end{array}$ & $\begin{array}{l}\text { Subkon } \\
\text { Office }\end{array}$ & Genset & $\begin{array}{c}\text { Rumah B3 } \\
\text { \& BBM }\end{array}$ & $\begin{array}{c}\text { Fabrikasi } \\
\text { Besi }\end{array}$ & $\begin{array}{c}\text { Fabrikasi } \\
\text { Baja }\end{array}$ & $\begin{array}{l}\text { Gudang } \\
\text { Logistik }\end{array}$ & $\begin{array}{c}\text { Los Kerja } \\
\text { Kayu }\end{array}$ \\
\hline 5 & $\begin{array}{c}\text { Site } \\
\text { Office }\end{array}$ & kir & $\begin{array}{l}\text { Toilet \& } \\
\text { Musholla }\end{array}$ & $\begin{array}{l}\text { Gudang } \\
\text { Logistik }\end{array}$ & $\begin{array}{c}\text { Kantor } \\
\text { K3 }\end{array}$ & $\begin{array}{l}\text { Subkon } \\
\text { Office }\end{array}$ & Genset & $\begin{array}{c}\text { Rumah B3 } \\
\text { \& BBM }\end{array}$ & $\begin{array}{c}\text { Fabrikasi } \\
\text { Besi }\end{array}$ & $\begin{array}{c}\text { Fabrikasi } \\
\text { Baja }\end{array}$ & $\begin{array}{l}\text { Gudang } \\
\text { Peralatan }\end{array}$ & $\begin{array}{c}\text { Los Kerja } \\
\text { Kayu }\end{array}$ \\
\hline 6 & $\begin{array}{c}\text { Site } \\
\text { Office }\end{array}$ & kir & $\begin{array}{l}\text { Toilet \& } \\
\text { Musholla }\end{array}$ & $\begin{array}{l}\text { Gudang } \\
\text { Peralatan }\end{array}$ & $\begin{array}{l}\text { Gudang } \\
\text { Logistik }\end{array}$ & $\begin{array}{l}\text { Subkon } \\
\text { Office }\end{array}$ & Genset & $\begin{array}{c}\text { Rumah B3 } \\
\text { \& BBM }\end{array}$ & $\begin{array}{l}\text { Fabrikasi } \\
\text { Baja }\end{array}$ & $\begin{array}{c}\text { Fabrikasi } \\
\text { Besi }\end{array}$ & $\begin{array}{c}\text { Kantor } \\
\mathrm{K} 3\end{array}$ & $\begin{array}{c}\text { Los Kerja } \\
\text { Kayu }\end{array}$ \\
\hline 7 & $\begin{array}{l}\text { Site } \\
\text { Office }\end{array}$ & $\mathrm{P}$ & $\begin{array}{l}\text { Toilet \& } \\
\text { Musholla }\end{array}$ & $\begin{array}{l}\text { Gudang } \\
\text { Logistik }\end{array}$ & $\begin{array}{l}\text { Gudang } \\
\text { Peralatan }\end{array}$ & $\begin{array}{c}\text { Los Kerja } \\
\text { Kayu }\end{array}$ & Genset & $\begin{array}{c}\text { Rumah B3 } \\
\text { \& BBM }\end{array}$ & $\begin{array}{c}\text { Fabrikasi } \\
\text { Baja }\end{array}$ & $\begin{array}{c}\text { Fabrikasi } \\
\text { Besi }\end{array}$ & $\begin{array}{c}\text { Kantor } \\
\text { K3 }\end{array}$ & $\begin{array}{l}\text { Subkon } \\
\text { Office }\end{array}$ \\
\hline 8 & $\begin{array}{c}\text { Site } \\
\text { Office }\end{array}$ & Parkir & $\begin{array}{l}\text { Toilet \& } \\
\text { Musholla }\end{array}$ & $\begin{array}{l}\text { Kantor } \\
\text { K3 }\end{array}$ & $\begin{array}{l}\text { Gudang } \\
\text { Peralatan }\end{array}$ & $\begin{array}{l}\text { Subkon } \\
\text { Office }\end{array}$ & Genset & $\begin{array}{c}\text { Rumah B3 } \\
\text { \& BBM }\end{array}$ & $\begin{array}{c}\text { Fabrikasi } \\
\text { Baja }\end{array}$ & $\begin{array}{c}\text { Fabrikasi } \\
\text { Besi }\end{array}$ & $\begin{array}{l}\text { Gudang } \\
\text { Logistik }\end{array}$ & $\begin{array}{c}\text { Los Kerja } \\
\text { Kayu }\end{array}$ \\
\hline 9 & $\begin{array}{c}\text { Site } \\
\text { Office }\end{array}$ & kir & $\begin{array}{l}\text { Toilet \& } \\
\text { Musholla }\end{array}$ & $\begin{array}{l}\text { Gudang } \\
\text { Logistik }\end{array}$ & $\begin{array}{l}\text { Kantor } \\
\text { K3 }\end{array}$ & $\begin{array}{l}\text { Subkon } \\
\text { Office }\end{array}$ & Genset & $\begin{array}{c}\text { Rumah B3 } \\
\text { \& BBM }\end{array}$ & $\begin{array}{c}\text { Fabrikasi } \\
\text { Baja }\end{array}$ & $\begin{array}{c}\text { Fabrikasi } \\
\text { Besi }\end{array}$ & $\begin{array}{l}\text { Gudang } \\
\text { Peralatan }\end{array}$ & $\begin{array}{c}\text { Los Kerja } \\
\text { Kayu }\end{array}$ \\
\hline 10 & $\begin{array}{c}\text { Site } \\
\text { Office }\end{array}$ & & $\begin{array}{l}\text { Toilet \& } \\
\text { Musholla }\end{array}$ & $\begin{array}{l}\text { Gudang } \\
\text { Peralatan }\end{array}$ & $\begin{array}{l}\text { Gudang } \\
\text { Logistik }\end{array}$ & $\begin{array}{l}\text { Los Kerja } \\
\text { Kayu }\end{array}$ & G & $\begin{array}{c}\text { Rumah B3 } \\
\text { \& BBM }\end{array}$ & $\begin{array}{c}\text { Fabrikasi } \\
\text { Besi }\end{array}$ & $\begin{array}{c}\text { Fabrikasi } \\
\text { Baja }\end{array}$ & $\begin{array}{c}\text { Kantor } \\
\text { K3 }\end{array}$ & $\begin{array}{l}\text { Subkon } \\
\text { Office }\end{array}$ \\
\hline 11 & $\begin{array}{c}\text { Site } \\
\text { Office }\end{array}$ & & $\begin{array}{l}\text { Toilet \& } \\
\text { Musholla }\end{array}$ & $\begin{array}{l}\text { Kantor } \\
\text { K3 }\end{array}$ & $\begin{array}{l}\text { Gudang } \\
\text { Peralatan }\end{array}$ & $\begin{array}{c}\text { Los Kerja } \\
\text { Kayu }\end{array}$ & Genset & $\begin{array}{c}\text { Rumah B3 } \\
\text { \& BBM }\end{array}$ & $\begin{array}{l}\text { Fabrikasi } \\
\text { Besi }\end{array}$ & $\begin{array}{c}\text { Fabrikasi } \\
\text { Baja }\end{array}$ & $\begin{array}{l}\text { Gudang } \\
\text { Logistik }\end{array}$ & $\begin{array}{l}\text { Subkon } \\
\text { Office }\end{array}$ \\
\hline 12 & $\begin{array}{c}\text { Site } \\
\text { Office }\end{array}$ & Parkir & $\begin{array}{l}\text { Toilet \& } \\
\text { Musholla }\end{array}$ & $\begin{array}{l}\text { Gudang } \\
\text { Logistik }\end{array}$ & $\begin{array}{l}\text { Kantor } \\
\text { K3 }\end{array}$ & $\begin{array}{c}\text { Los Kerja } \\
\text { Kayu }\end{array}$ & Genset & $\begin{array}{c}\text { Rumah B3 } \\
\text { \& BBM }\end{array}$ & $\begin{array}{c}\text { Fabrikasi } \\
\text { Besi }\end{array}$ & $\begin{array}{c}\text { Fabrikasi } \\
\text { Baja }\end{array}$ & $\begin{array}{l}\text { Gudang } \\
\text { Peralatan }\end{array}$ & $\begin{array}{c}\text { Subkon } \\
\text { Office }\end{array}$ \\
\hline 13 & $\begin{array}{l}\text { Site } \\
\text { Office }\end{array}$ & & $\begin{array}{l}\text { Toilet \& } \\
\text { Musholla }\end{array}$ & $\begin{array}{l}\text { Gudang } \\
\text { Peralatan }\end{array}$ & & $\begin{array}{c}\text { Los Kerja } \\
\text { Kayu }\end{array}$ & Genset & & Fabrikasi & Fabrikasi & $\begin{array}{c}\text { Kantor } \\
\text { K3 }\end{array}$ & \\
\hline 14 & $\begin{array}{c}\text { Site } \\
\text { Office }\end{array}$ & & $\begin{array}{l}\text { Toilet \& } \\
\text { Musholla }\end{array}$ & $\begin{array}{l}\text { Kantor } \\
\text { K3 }\end{array}$ & $\begin{array}{l}\text { Gudang } \\
\text { Peralatan }\end{array}$ & $\begin{array}{c}\text { Los Kerja } \\
\text { Kayu }\end{array}$ & Genset & $\begin{array}{c}\text { Rumah B3 } \\
\text { \& BBM }\end{array}$ & $\begin{array}{l}\text { Fabrikasi } \\
\text { Baja }\end{array}$ & $\begin{array}{c}\text { Fabrikasi } \\
\text { Besi }\end{array}$ & $\begin{array}{l}\text { Gudang } \\
\text { Logistik }\end{array}$ & $\begin{array}{l}\text { Subkon } \\
\text { Office }\end{array}$ \\
\hline 15 & $\begin{array}{c}\text { Site } \\
\text { Office }\end{array}$ & & $\begin{array}{l}\text { Toilet \& } \\
\text { Musholla }\end{array}$ & $\begin{array}{l}\text { Gudang } \\
\text { Logistik }\end{array}$ & $\begin{array}{c}\text { Kantor } \\
\mathrm{K} 3\end{array}$ & $\begin{array}{c}\text { Los Kerja } \\
\text { Kayu }\end{array}$ & Genset & $\begin{array}{c}\text { Rumah B3 } \\
\text { \& BBM }\end{array}$ & $\begin{array}{c}\text { Fabrikasi } \\
\text { Baja }\end{array}$ & $\begin{array}{c}\text { Fabrikasi } \\
\text { Besi }\end{array}$ & $\begin{array}{l}\text { Gudang } \\
\text { Peralatan }\end{array}$ & $\begin{array}{l}\text { Subkon } \\
\text { Office }\end{array}$ \\
\hline
\end{tabular}

$$
\text { Traveling Distance }(T D)=\sum_{i, j=1}^{n} d_{i j} x F_{i j}
$$

Dan perhitungan Safety Index menggunakan rumus [3] :

$$
\text { Safety Index }(S I)=\sum_{i, j=1}^{n} s_{i j} x F_{i j}
$$

Dimana

$\mathrm{n} \quad=$ jumlah fasilitas total pada proyek

$d_{i j} \quad=$ jarak aktual antara fasilitas I dan $\mathrm{j}$

$s_{i j} \quad=$ tingkat keamanan dan keselamatan (safety) antar fasilitas $\mathrm{i}$ dan $\mathrm{j}$

$F_{i j} \quad=$ frekuensi perpindahan antar fasilitas I dan $\mathrm{j}$

Berikut merupakan hasil perhitungan Traveling Distance dan Safety Index masing-masing alternatif :

\section{Alternatif 0 (kondisi asli)}

Alternatif 0 adalah kondisi eksisting letak fasilitas pendukung proyek. Belum ada fasilitas yang saling ditukar. Adapun hasil yang diperoleh setelah melakukan perhitungan adalah $\mathrm{TD}=64.973,2$ meter dan $\mathrm{SI}=2.543,88$.

\section{Alternatif 1}

Pada alternatif 1 terdapat 2 fasilitas yang saling ditukar, yaitu Fabrikasi Besi dengan Fabrikasi Baja. Adapun hasil yang diperoleh setelah melakukan perhitungan adalah TD $=65.247$ meter. Hasil ini menunjukan bahwa TD mengalami kenaikan sebesar $0,42 \%$ dari kondisi asli. Sedangkan hasil perhitungan SI 
$=2.570,29$. Hasil ini menunjukan bahwa SI mengalami kenaikan sebesar 1,04\% dari kondisi asli.

\section{Alternatif 2}

Pada alternatif 2 terdapat 2 fasilitas yang saling ditukar, yaitu Gudang Peralatan dan Gudang Logistik. Adapun hasil yang diperoleh setelah melakukan perhitungan adalah $\mathrm{TD}=$ 64.590,6 meter. Hasil ini menunjukan bahwa TD mengalami penurunan sebesar $0,59 \%$ dari kondisi asli. Sedangkan hasil perhitungan SI $=2.548,80$. Hasil ini menunjukan bahwa SI mengalami kenaikan sebesar 0,19\% dari kondisi asli.

\section{Alternatif 3}

Pada alternatif 3 terdapat 2 fasilitas yang saling ditukar, yaitu Los Kerja Kayu dengan Subkon Office. Adapun hasil yang diperoleh setelah melakukan perhitungan adalah $\mathrm{TD}=$ 64.445 meter. Hasil ini menunjukan bahwa TD mengalami penurunan sebesar $0,81 \%$ dari kondisi asli. Sedangkan hasil perhitungan SI $=2.337,32$. Hasil ini menunjukan bahwa SI mengalami penurunan sebesar $8,12 \%$ dari kondisi asli.

\section{Alternatif 4}

Pada alternatif 4 terdapat 2 fasilitas yang saling ditukar, yaitu Kantor K3 dengan Gudang Logistik. Adapun hasil yang diperoleh setelah melakukan perhitungan adalah TD $=64.909,9$ meter. Hasil ini menunjukan bahwa TD mengalami penurunan sebesar $0,10 \%$ dari kondisi asli. Sedangkan hasil perhitungan SI $=2.539,81$. Hasil ini menunjukan bahwa SI mengalami penurunan sebesar $0,16 \%$ dari kondisi asli.

\section{Alternatif 5}

Pada alternatif 5 terdapat 2 fasilitas yang saling ditukar, yaitu Kantor K3 dengan Gudang Peralatan. Adapun hasil yang diperoleh setelah melakukan perhitungan adalah $\mathrm{TD}=62.259$ meter. Hasil ini menunjukan bahwa TD mengalami penurunan sebesar 4,18\% dari kondisi asli. Sedangkan hasil perhitungan SI $=2.521,04$. Hasil ini menunjukan bahwa SI mengalami penurunan sebesar $0,90 \%$ dari kondisi asli.

\section{Alternatif 6}

Pada alternatif 6 terdapat 4 fasilitas yang saling ditukar, yaitu Gudang Peralatan dengan Gudang Logistik dan Fabrikasi Baja dengan Fabrikasi Besi. Adapun hasil yang diperoleh setelah melakukan perhitungan adalah $\mathrm{TD}=64.837$ meter. Hasil ini menunjukan bahwa TD mengalami penurunan sebesar $0,21 \%$ dari kondisi asli. Sedangkan hasil perhitungan SI $=$ 2.576,35. Hasil ini menunjukan bahwa SI mengalami kenaikan sebesar $1,28 \%$ dari kondisi asli.

\section{Alternatif 7}

Pada alternatif 7 terdapat 4 fasilitas yang saling ditukar, yaitu Los Kerja Kayu dengan Subkon Office dan Fabrikasi Baja dengan Fabrikasi Besi. Adapun hasil yang diperoleh setelah melakukan perhitungan adalah TD $=64.222,8$ meter. Hasil ini menunjukan bahwa TD mengalami penurunan sebesar $1,15 \%$ dari kondisi asli. Sedangkan hasil perhitungan SI $=2.347,83$. Hasil ini menunjukan bahwa SI mengalami penurunan sebesar $7,71 \%$ dari kondisi asli.

\section{Alternatif 8}

Pada alternatif 8 terdapat 4 fasilitas yang saling ditukar, yaitu Kantor K3 dengan Gudang Logistik dan Fabrikasi Baja dengan Fabrikasi Besi. Adapun hasil yang diperoleh setelah melakukan perhitungan adalah TD $=65.180,9$ meter. Hasil ini menunjukan bahwa TD mengalami kenaikan sebesar 0,32\% dari kondisi asli. Sedangkan hasil perhitungan SI $=2.567,72$. Hasil ini menunjukan bahwa SI mengalami kenaikan sebesar $0,94 \%$ dari kondisi asli.

\section{Alternatif 9}

Pada alternatif 9 terdapat 4 fasilitas yang saling ditukar, yaitu Kantor K3 dengan Gudang Peralatan dan Fabrikasi Baja dengan Fabrikasi Besi. Adapun hasil yang diperoleh setelah melakukan perhitungan adalah TD $=58.409,5$ meter. Hasil ini menunjukan bahwa TD mengalami penurunan sebesar 10,10\% dari kondisi asli. Sedangkan hasil perhitungan SI $=2.353,99$. Hasil ini menunjukan bahwa SI mengalami penurunan sebesar $7,46 \%$ dari kondisi asli.

\section{Alternatif 10}

Pada alternatif 10 terdapat 4 fasilitas yang saling ditukar, yaitu Los Kerja Kayu dengan Subkon Office dan Gudang Peralatan dengan Gudang Logistik. Adapun hasil yang diperoleh setelah melakukan perhitungan adalah $\mathrm{TD}=63.787,2$ meter. Hasil ini menunjukan bahwa TD mengalami penurunan sebesar 1,83\% dari kondisi asli. Sedangkan hasil perhitungan SI $=2.346,56$. Hasil ini menunjukan bahwa SI mengalami penurunan sebesar 7,76\% dari kondisi asli.

\section{Alternatif 11}

Pada alternatif 11 terdapat 4 fasilitas yang saling ditukar, yaitu Los Kerja Kayu dengan Subkon Office dan Kantor K3 dengan Gudang Logistik. Adapun hasil yang diperoleh setelah melakukan perhitungan adalah TD $=65.274,5$ meter. Hasil ini menunjukan bahwa TD mengalami kenaikan sebesar 0,46\% dari kondisi asli. Sedangkan hasil perhitungan SI $=2.344,27$. Hasil ini menunjukan bahwa SI mengalami penurunan sebesar 7,85\% dari kondisi asli.

\section{Alternatif 12}

Pada alternatif 12 terdapat 4 fasilitas yang saling ditukar, yaitu Los Kerja Kayu dengan Subkon Office dan Kantor K3 dengan Gudang Peralatan. Adapun hasil yang diperoleh setelah melakukan perhitungan adalah TD $=62596$ meter. Hasil ini menunjukan bahwa TD mengalami penurunan sebesar 3,66\% dari kondisi asli. Sedangkan hasil perhitungan SI $=2.314,69$. Hasil ini menunjukan bahwa SI mengalami penurunan sebesar 9,01\% dari kondisi asli.

\section{Alternatif 13}

Pada alternatif 13 terdapat 6 fasilitas yang saling ditukar, yaitu Fabrikasi Besi dengan Fabrikasi Baja, Gudang Peralatan dengan Gudang Logistik, dan Los Kerja Kayu dengan Subkon Office. Adapun hasil yang diperoleh setelah melakukan perhitungan adalah $\mathrm{TD}=63.537,6$ meter. Hasil ini menunjukan bahwa TD mengalami penurunan sebesar $2,21 \%$ dari kondisi asli. Sedangkan hasil perhitungan SI $=2.358,20$. Hasil ini menunjukan bahwa SI mengalami penurunan sebesar 7,30\% dari kondisi asli.

\section{Alternatif 14}

Pada alternatif 14 terdapat 6 fasilitas yang saling ditukar, yaitu Fabrikasi Besi dengan Fabrikasi Baja, Los Kerja Kayu dengan Subkon Office, dan Kantor K3 dengan Gudang Logistik. Adapun hasil yang diperoleh setelah melakukan perhitungan adalah $\mathrm{TD}=65.049,5$ meter. Hasil ini menunjukan bahwa TD mengalami kenaikan sebesar $0,12 \%$ dari kondisi asli. Sedangkan hasil perhitungan SI $=2.356,27$. Hasil ini menunjukan bahwa SI mengalami penurunan sebesar 7,37\% dari kondisi asli. 


\section{Alternatif 15}

Pada alternatif 14 terdapat 6 fasilitas yang saling ditukar, yaitu Fabrikasi Besi dengan Fabrikasi Baja, Los Kerja Kayu dengan Subkon Office, dan Kantor K3 dengan Gudang Peralatan. Adapun hasil yang diperoleh setelah melakukan perhitungan adalah TD $=62.374,6$ meter. Hasil ini menunjukan bahwa TD mengalami penurunan sebesar $4 \%$ dari kondisi asli. Sedangkan hasil perhitungan SI $=2.325,32$. Hasil ini menunjukan bahwa SI mengalami penurunan sebesar $8,59 \%$ dari kondisi asli.

Tabel 7.

\begin{tabular}{ccccccc}
\multicolumn{7}{c}{ Hasil Perhitungan TD dan SI } \\
\hline \hline Alt. & TD & Selisih & $\%$ & SI & Selisih & $\%$ \\
\hline 0 & 64973.2 & 0 & 0.00 & 2543.88 & 0 & 0 \\
1 & 65247 & 273.8 & -0.42 & 2570.29 & 26.416 & -1.04 \\
2 & 64590.6 & -382.6 & 0.59 & 2548.80 & 4.924 & -0.19 \\
3 & 64445 & -528.2 & 0.81 & 2337.32 & -206.56 & 8.12 \\
4 & 64909.9 & -63.3 & 0.10 & 2539.81 & -4.064 & 0.16 \\
5 & 62259 & -2714.2 & 4.18 & 2521.04 & -22.838 & 0.90 \\
6 & 64837 & -136.2 & 0.21 & 2576.35 & 32.472 & -1.28 \\
7 & 64222.8 & -750.4 & 1.15 & 2347.83 & -196.048 & 7.71 \\
8 & 65180.9 & 207.7 & -0.32 & 2567.72 & 23.84 & -0.94 \\
9 & 58409.5 & -6563.7 & 10.10 & 2353.99 & -189.886 & 7.46 \\
10 & 63787.2 & -1186 & 1.83 & 2346.56 & -197.316 & 7.76 \\
11 & 65274.5 & 301.3 & -0.46 & 2344.27 & -199.608 & 7.85 \\
12 & 62596 & -2377.2 & 3.66 & 2314.69 & -229.182 & 9.01 \\
13 & 63537.6 & -1435.6 & 2.21 & 2358.20 & -185.672 & 7.30 \\
14 & 65049.5 & 76.3 & -0.12 & 2356.27 & -187.608 & 7.37 \\
15 & 62374.6 & -2598.6 & 4.00 & 2325.32 & -218.554 & 8.59 \\
\hline \hline
\end{tabular}

Negatif dalam kolom \% pada Tabel 7 artinya terjadi kenaikan, sedangkan positif artinya terjadi penurunan.

Dari perhitungan 15 alternatif Traveling Distance dan Safety Index, maka selanjutnya hasil perhitungan tersebut di plot ke dalam sebuah diagram.

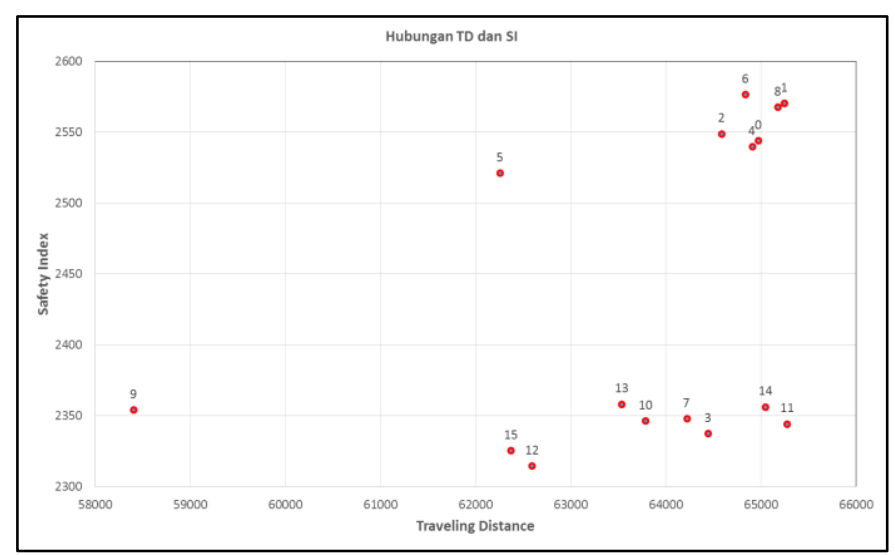

Gambar 3. Diagram Hubungan TD dan SI

Dari gambar diagram tersebut dapat dilihat bahwa hasil Alternatif 9 dan Alternatif 12 merupakan hasil yang paling optimal karena memiliki nilai TD dan SI yang paling minimum dibanding dengan Alternatif lainnya.

Tabel 8.

Alternatif-Alternatif yang Paling Optimum

\begin{tabular}{ccccccc}
\hline \hline & \multicolumn{3}{c}{ Traveling Distance } & \multicolumn{3}{c}{ Safety Index } \\
Alt. & Nilai & $\begin{array}{c}\text { Kenaikan } \\
(\%)\end{array}$ & $\begin{array}{c}\text { Penurunan } \\
(\%)\end{array}$ & Nilai & $\begin{array}{c}\text { Kenaikan } \\
(\%)\end{array}$ & $\begin{array}{c}\text { Penurunan } \\
(\%)\end{array}$ \\
\hline 9 & $58.409,5$ & - & 10,10 & $2.353,99$ & - & 7,46 \\
12 & 62.596 & - & 3,66 & $2.314,69$ & - & 9,01 \\
\hline \hline
\end{tabular}

Selanjutnya untuk menentukan Site Layout yang paling optimal dilakukan dengan cara menggunakan perbandingan presentase nilai jarak (TD) dan tingkat keamanan (SI) yang didapat dari pihak kontraktor, yaitu PT. PP (Persero) Tbk. Presentase yang diberikan untuk nilai jarak tempuh (TD) sebesar 30\% dan nilai tingkat keamanan (SI) sebesar 70\%. Nilai tersebut selanjutnya dikalikan dengan presentase kenaikan atau penurunan nilai jarak tempuh (TD) dan nilai tingkat keamanan (SI) pada alternatif 9 dan Alternatif 12. Berikut adalah hasil perhitungan :

$$
\begin{aligned}
\text { Alternatif } 9 & =30 \% \times \text { Presentase } \mathrm{TD}+70 \% \times \text { Presentase SI } \\
& =30 \% \times 10,10+70 \% \times 7,46 \\
& =8,26 \%
\end{aligned}
$$

$$
\begin{aligned}
\text { Alternatif } 12 & =30 \% \text { x Presentase TD }+70 \% \text { x Presentase SI } \\
& =30 \% \text { x } 3,66+70 \% \text { x } 9,01 \\
& =7,40 \%
\end{aligned}
$$

Dari perhitungan diatas bisa kita ketahui bahwa hasil penjumlahan dari perkalian nilai TD dan nilai SI yang paling besar terdapat pada Alternatif 9. Maka, Alternatif 9 dipilih sebagai bentuk Site Layout yang paling optimum.

\section{KESIMPULAN}

Berdasarkan hasil analisis dan perhitungan yang telah dilakukan, dapat disimpulkan bahwa Site Layout pada proyek pembangunan Transmart Rungkut Surabaya belum optimal bila ditinjau dari Traveling Distance dan Safety Index. Berdasarkan hasil plot pada Scatter Diagram, didapatkan nilai TD yang paling minimum yaitu pada Alternatif 9 dengan nilai TD sebesar 59.409,5 meter atau mengalami penurunan nilai TD sebesar 10,10\% bila dibandingkan dengan nilai TD kondisi asli. Sedangkan untuk nilai SI yang paling minimum yaitu pada Alternatif 12 dengan nilai SI sebesar 2.314,69 atau mengalami penurunan sebesar $9,01 \%$ bila dibandingkan dengan nilai SI kondisi asli. Namun kedua alternatif tidak dapat dibandingkan satu sama lain karena memiliki keunggulan masing-masing pada nilai TD dan SI. Sehingga untuk menentukan Site Layout yang paling optimum, ditentukan dengan cara merujuk pada pembobotan dari kontraktor pelaksana yang memberikan pembobotan 30\% untuk nilai TD dan 70\% untuk nilai SI. Hasil pembobotan yang dilakukan didapatkan bahwa Alternatif 9 merupakan Alternatif bentuk Site Layout yang paling optimum dengan nilai penurunan gabungan nilai TD dan SI sebesar $8,26 \%$.

\section{DAFTAR PUSTAKA}

[1] Tommelein, I.D., Levitt, R.E., Hayes-Roth, B., \& Confrey, T. 1991. "SightPlan Experiments : Alternate Strategies for Site Layout Design". ASCE Journal of Computing in Civil Engineering, 5, no.1, p.42-63

[2] Yeh, I.C. 1995. "Construction Site Layout Using Annealed Neural Network". Journal of Computing in Civil Engineering, 9(3) 201-208

[3] Effendi, D.T. 2012. Optimasi Site Layout Menggunakan MultiObjectives Function Pada Proyek Pembangunan Apartemen Puncak Kertajaya Surabaya. Surabaya : Institut Teknologi Sepuluh Nopember. 